\section{Release of subducted sedimentary nitrogen throughout Earth's mantle}

P.H. Barry ${ }^{1,2 *}$, D.R. Hilton

\section{Abstract}

The dynamic process of subduction represents the principal means to introduce chemical heterogeneities into Earth's interior. In the case of nitrogen $(\mathrm{N})$ - atmosphere's most abundant gas - biological-activity converts $\mathrm{N}_{2}$ into ammonium ions $\left(\mathrm{NH}_{4}{ }^{+}\right)$, which are chemicallybound within seafloor sediments and altered oceanic crust that comprise the subducting slab. Although some subducted N re-emerges via arc-related volcanism (Sano et al., 1998; Fischer et al., 2002), the majority likely bypasses sub-arc depths (150-200 km) and supplies the deeper mantle (Li et al., 2007; Mitchell et al., 2010; Johnson and Goldblatt, 2015; Bebout et al., 2016). However, the fate of subducted $\mathrm{N}$ remains enigmatic: is it incorporated by the shallow convecting mantle - the source of ridge volcanism, or is the deeper mantle - nominally associated with mantle plumes - its ultimate repository? Here, we present N-He-Ne-A isotope data for oceanic basalts from the Central Indian Ridge (CIR)-Réunion plume region to address this issue. All on-axis samples with depleted MORB mantle (DMM) affinitie $\left({ }^{3} \mathrm{He} /{ }^{4} \mathrm{He}=8 \pm 1 \mathrm{R}_{\mathrm{A}} ;\right.$ Graham, 2002) have low $\mathrm{N}$-isotopes (mean $\delta^{15} \mathrm{~N}=-2.1 \%$ ), whereas those with plume-like ${ }^{3} \mathrm{He} /{ }^{4} \mathrm{He}$ display higher values (mean $\delta^{15} \mathrm{~N}=1.3 \%$ ). We explain these data within the framework of a new mantle reference model to predict a time-integrated net $\mathrm{N}$ regassing flux to the mantle of $\sim 3.4 \times 10^{10} \mathrm{~mol} / \mathrm{yr}$, with the plume-source mantle representing the preferential destination by a factor of $2-3$. The model has implications for the present-day imbalance between $\mathrm{N}$ subducted at trenches and $\mathrm{N}$ emitted via arc-related volcanism, the $\mathrm{N}$-content of Earth's early atmosphere, as well as relationships between $\mathrm{N}_{2}$ and the noble gases in mantle reservoirs, including ${ }^{3} \mathrm{He} /{ }^{4} \mathrm{He}-\delta^{15} \mathrm{~N}$ relationships in plumederived lavas.

Received 3 February 2016 | Accepted 11 April 2016 | Published 3 May 2016

\section{Letter}

The CIR-Réunion plume system is a classic modern example of oblique plumeridge interaction, with the present-day plume centred at Réunion Island and three submarine off-ridge segments, the Rodriguez, Three Magi and Gasitao ridges,

1. Fluids \& Volatiles Laboratory, Scripps Institution of Oceanography, UC San Diego, La Jolla, California 92093-0244, USA

Present address: Department of Earth Sciences, University of Oxford, OX1 3AN, UK

Corresponding author (email: peter.barry@earth.ox.ac.uk)

connecting with the CIR ridge axis located $\sim 1100 \mathrm{~km}$ to the east. These westto-east trending ridges were formed by volcanism above a channel of Réunion hotspot mantle as the CIR migrated northeast over and away from the plume (Morgan, 1978). He-isotopes - the canonical tracer of mantle plume involvement in petrogenesis - are higher $\left(>9 R_{A}\right)$ than typical DMM values of $8 \pm 1 R_{A}$ (where $\mathrm{R}_{\mathrm{A}}=$ air-like ${ }^{3} \mathrm{He} /{ }^{4} \mathrm{He}$ ) at Réunion Island and along the off-axis ridges. In contrast, the CIR exhibits DMM-like ${ }^{3} \mathrm{He} /{ }^{4} \mathrm{He}$ values along axis, except at the point where the projection of the submarine ridges meets the ridge axis $\sim 19.9^{\circ} \mathrm{S}$ (Füri et al., 2011; Fig. S-1).

New nitrogen isotope and abundance analyses, along with accompanying neon and argon data, of basaltic glasses from the CIR axis between $16.7^{\circ} \mathrm{S}$ and $20.6^{\circ} \mathrm{S}$, and from the off-axis ridges to the west of the CIR (Fig. S-1) are presented in Table $1 \mathrm{a}$ and $\mathrm{b}$. In addition, we report $\mathrm{Ne}$ and $\mathrm{Ar}$ isotope and abundance data on olivine separates of a suite of cumulate dunite xenoliths from Réunion Island. Samples were processed by vacuum crushing with released gases analysed using a noble gas mass spectrometer (Barry et al., 2012). All samples have been analysed previously for He isotopes, major/minor and trace element chemistry (Für et al., 2011).

Nitrogen isotope results are presented in the $\delta^{15} \mathrm{~N}$ notation (where $\delta^{15} \mathrm{~N}=$ $\left.\left(\left({ }^{15} \mathrm{~N} /{ }^{14} \mathrm{~N}_{\text {sample }} /{ }^{15} \mathrm{~N} /{ }^{14} \mathrm{~N}_{\text {air }}\right)-1\right) \times 1000\right)$ and plotted against He isotopes in Figure $1 \mathrm{a}$ and displayed in comparison to the $\delta^{15} \mathrm{~N}$ database of ocean basalts in Figure $1 \mathrm{~b}$. We highlight the following key features of the $\mathrm{N}$-isotope results. First, all on-axis samples (with the exception of D9-2; $\delta^{15} \mathrm{~N}=1.16 \%$ ) have negative $\delta^{15} \mathrm{~N}$ values The highest and lowest values are -0.10 and $-3.8 \%$ giving an on-axis $\delta^{15} \mathrm{~N}$ mean value of $-2.1 \pm 1.1 \%$ o $(1 \sigma ; n=7)$ or $-1.7 \pm 1.6 \%$ ( $n=8$ if D9-2 is included). Notably, sample D9-2 has a ${ }^{3} \mathrm{He} /{ }^{4} \mathrm{He}$ ratio $\left(7.25 \mathrm{R}_{\mathrm{A}}\right)$, which falls in the nominal DMM range $\left(8 \pm 1 \mathrm{R}_{\mathrm{A}}\right.$; Graham, 2002) characteristic of most samples on the CIR ridge-axis (Füri et al., 2011). The only on-axis sample (DR10-1) of the present sample suite with a ${ }^{3} \mathrm{He} /{ }^{4} \mathrm{He}$ value higher than DMM $\left({ }^{3} \mathrm{He} /{ }^{4} \mathrm{He}=10.31 \mathrm{R}_{\mathrm{A}}\right)$ is from the region where the projection of the off-axis ridge impinges the spreading centre $\left(\sim 19.9^{\circ} \mathrm{S}\right)$ : it has a $\delta^{15} \mathrm{~N}$ value of $-0.10 \%$ - the second highest value of the on-axis samples. Second, the three off-axis samples - all with ${ }^{3} \mathrm{He} /{ }^{4} \mathrm{He}>9 \mathrm{R}_{\mathrm{A}}$ - have positive $\delta^{15} \mathrm{~N}$ values, ranging from +0.89 to $+1.80 \%$; with a mean value of $1.3 \pm 0.7 \%$ o $(1 \sigma)$ Thus, with the exception of sample D9-2, there is a clear distinction between relatively low $\delta^{15} \mathrm{~N}$ values associated with DMM-like He-isotopes on the ridge axis and relatively high $\delta^{15} \mathrm{~N}$ values associated with plume-like ${ }^{3} \mathrm{He} /{ }^{4} \mathrm{He}$ values off-axis. Finally, we point out that with the exception of sample D8-2, all $\delta^{15} \mathrm{~N}$ values, irrespective of location on- or off-axis, are higher than the range nominally associated with DMM $\left(\delta^{15} \mathrm{~N}=-5 \pm 2 \%\right.$; Fig. $\left.1 \mathrm{~b}\right)$. Thus, samples of this study have experienced enrichment in ${ }^{15} \mathrm{~N}$ compared to the majority of basalts erupted at ridge axes worldwide.

There are three processes capable of producing high $(>\mathrm{DMM}) \delta^{15} \mathrm{~N}$ signatures in CIR basalts: (1) assimilation of existing crust during magma eruption likely also involving incorporation of air $\left(\delta^{15} \mathrm{~N}=0 \%\right.$, (2) mass-dependent 
Table 1a Neon and argon isotope systematics of submarine basaltic glasses from the CIR (on-axis) and adjacent (off-axis) Gasitao Ridge, Three Magi Ridges and Abyssal Hill, and olivine separates from dunite xenoliths of Piton Chisny (Réunion).

\begin{tabular}{|c|c|c|c|c|c|}
\hline Sample & ${ }^{20} \mathrm{Ne} /{ }^{22} \mathrm{Ne}$ & ${ }^{21} \mathrm{Ne} /{ }^{22} \mathrm{Ne}$ & $\begin{array}{c}{ }^{20} \mathrm{Ne} \times 10^{-9} \mathrm{~cm}^{3} \\
\text { STP/g }\end{array}$ & ${ }^{40} \mathrm{Ar} /{ }^{36} \mathrm{Ar}$ & $\begin{array}{l}{\left[{ }^{40} \mathrm{Ar}\right] \times 10^{-9}} \\
\mathrm{~cm}^{3} \mathrm{STP} / \mathrm{g}\end{array}$ \\
\hline \multicolumn{6}{|l|}{ On-Axis } \\
\hline D1-1 & $10.10 \pm 0.11$ & $0.0316 \pm 0.0003$ & $0.67 \pm 0.012$ & $290.6 \pm 0.1$ & $2416 \pm 0.3$ \\
\hline D1-1 (Dup) & & - & - & - & - \\
\hline D3-1 & $9.90 \pm 0.10$ & $0.0291 \pm 0.0001$ & $2.28 \pm 0.025$ & $296.1 \pm 0.3$ & $765 \pm 0.5$ \\
\hline D2-1 & $9.85 \pm 0.10$ & $0.0295 \pm 0.0003$ & $2.21 \pm 0.030$ & $349.4 \pm 0.3$ & $1415 \pm 0.9$ \\
\hline D8-2 & $9.93 \pm 0.10$ & $0.0302 \pm 0.0002$ & $0.76 \pm 0.017$ & $3520 \pm 12$ & $724 \pm 0.2$ \\
\hline D9-2 & - & - & - & - & - \\
\hline D15-1 & $10.34 \pm 0.11$ & $0.0327 \pm 0.0004$ & $0.55 \pm 0.008$ & $2193 \pm 3.3$ & $1968 \pm 2.6$ \\
\hline D14-1 & $10.34 \pm 0.12$ & $0.0324 \pm 0.0008$ & $0.25 \pm 0.019$ & $2413 \pm 5.8$ & $1326 \pm 0.3$ \\
\hline D14-1 (Dup) & $10.43 \pm 0.11$ & $0.0331 \pm 0.0004$ & $0.25 \pm 0.012$ & $1514 \pm 3.9$ & $761 \pm 0.7$ \\
\hline DR10-1 & & & & & \\
\hline D13-1 & $10.72 \pm 0.12$ & $0.0340 \pm 0.0006$ & $0.20 \pm 0.023$ & $3519 \pm 12$ & $722 \pm 0.2$ \\
\hline D13-1 (Dup) & $11.32 \pm 0.13$ & $0.0401 \pm 0.0007$ & $0.10 \pm 0.004$ & $8487 \pm 43$ & $1272 \pm 0.5$ \\
\hline \multicolumn{6}{|c|}{$\begin{array}{l}\text { Off-Axis } \\
\text { Three Magi Ridges }\end{array}$} \\
\hline D22-1 & $9.89 \pm 0.10$ & $0.0296 \pm 0.0002$ & $1.89 \pm 0.011$ & $408.5 \pm 0.6$ & $1903 \pm 0.8$ \\
\hline D22-1 (Dup \#1) & & - & - & - & - \\
\hline D22-1 (Dup \#2) & - & - & - & - & - \\
\hline D26-2 & $9.87 \pm 0.10$ & $0.0296 \pm 0.0002$ & $1.15 \pm 0.025$ & $554.6 \pm 0.5$ & $1268 \pm 0.9$ \\
\hline \multicolumn{6}{|l|}{ Gasitao Ridge } \\
\hline D20-5 & $9.84 \pm 0.23$ & $0.0294 \pm 0.0013$ & $0.17 \pm 0.020$ & $1725 \pm 12$ & $421 \pm 0.1$ \\
\hline D20-5 (Dup \#1) & $10.05 \pm 0.13$ & $0.0304 \pm 0.0009$ & $0.12 \pm 0.007$ & $1786 \pm 4.8$ & $383 \pm 0.1$ \\
\hline D20-5 (Dup \#2) & $10.05 \pm 0.12$ & $0.0317 \pm 0.0010$ & $0.14 \pm 0.013$ & $1576 \pm 5.2$ & $401 \pm 0.3$ \\
\hline D18-1 & $9.89 \pm 0.11$ & $0.0290 \pm 0.0004$ & $0.14 \pm 0.006$ & $396.1 \pm 3.0$ & $16 \pm 0.1$ \\
\hline \multicolumn{6}{|l|}{ Abyssal Hill } \\
\hline D37-2 & $9.86 \pm 0.10$ & $0.0294 \pm 0.0001$ & $1.19 \pm 0.022$ & $318.4 \pm 0.4$ & $849 \pm 0.7$ \\
\hline \multicolumn{6}{|l|}{ Réunion Island } \\
\hline CH07-01 & $10.49 \pm 0.11$ & $0.0306 \pm 0.0005$ & $0.30 \pm 0.006$ & $1294 \pm 3.0$ & $776 \pm 0.2$ \\
\hline CH07-02 & $10.00 \pm 0.11$ & $0.0296 \pm 0.0004$ & $0.33 \pm 0.007$ & $501.2 \pm 1.0$ & $327 \pm 0.2$ \\
\hline CH07-04 & $10.09 \pm 0.12$ & $0.0314 \pm 0.0014$ & $0.06 \pm 0.007$ & $705.1 \pm 3.5$ & $125 \pm 0.1$ \\
\hline CH07-07 & $10.26 \pm 0.11$ & $0.0296 \pm 0.0008$ & $0.20 \pm 0.006$ & $831.3 \pm 2.0$ & $308 \pm 0.1$ \\
\hline
\end{tabular}




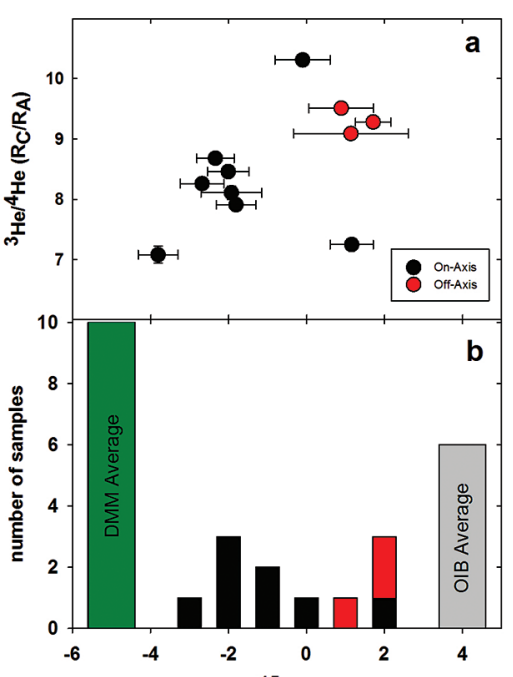

$\delta^{15} \mathrm{~N}(\%)$

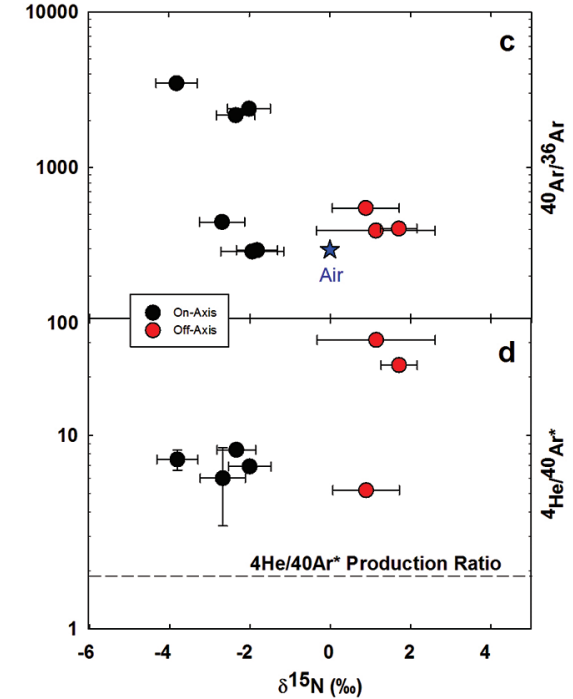

Figure 1 (a) He-isotopes $\left({ }^{3} \mathrm{He} /{ }^{4} \mathrm{He}\right.$ ) versus $\mathrm{N}$-isotopes, showing high (positive) $\delta^{15} \mathrm{~N}$ values in all off-axis samples with $>\mathrm{DMM}$-like ${ }^{3} \mathrm{He} /{ }^{4} \mathrm{He}$ - values. (b) Histogram of $\mathrm{N}$-isotopes measured alloff-axis sam (in black) and its adjacent ridges (in red) relative to of along the CIR (in black) and its adjacent ridges (in red) relative to global DMM (green) and N-isotop. (d) ${ }^{4} \mathrm{H}^{40} \mathrm{Ar}^{*}$ (degassing $\mathrm{roxy}$ ) versus $\mathrm{N}$-isotopes suggests that high $\delta^{15} \mathrm{~N}$ values are not produced by magmatic degassing (see text).

fractionation related to magmatic degassing (Cartigny et al., 2001), and/or (3) recycling of oceanic sediments and/or oceanic crust $\left(\delta^{15} \mathrm{~N} \sim+5\right.$ to $+7 \%$ o) into the CIR mantle source region producing the melts (Marty and Dauphas, 2003). The latter possibility implies that $\delta^{15} \mathrm{~N}$ is a feature intrinsic to the mantle source, whereas the former two are predominantly shallow-level phenomena that act to mask primary (source) $\delta^{15} \mathrm{~N}$ signatures.

There is little evidence in either the on- or off-axis $\mathrm{N}$ database (Table 1a and b) for a correlation between high $\mathrm{N}$-contents - possibly reflecting crustal assimilation and/or air addition - and high $\delta^{15} \mathrm{~N}$ values. For example, there is a 30-fold difference in N-content between off-axis samples D22-1 and D18-1 yet they have indistinguishable $\delta^{15} \mathrm{~N}$ values. Similarly, two of the three highest $\mathrm{N}$-content on-axis samples (D8-2 and D15-1) have the lowest $\delta^{15} \mathrm{~N}$ values of this suite. Both observations are inconsistent with addition of air and/or crustal $\mathrm{N}$ which would act to increase both $\delta^{15} \mathrm{~N}$ and $\mathrm{N}$-content of samples. Furthermore, a plot of ${ }^{40} \mathrm{Ar} /{ }^{36} \mathrm{Ar}$ versus $\delta^{15} \mathrm{~N}$ (Fig. 1c) shows no correlation for either on- or off-axis samples: all on-axis samples fall within $2 \sigma$ of the mean value of -2.1 $\%$, yet ${ }^{40} \mathrm{Ar} /{ }^{36} \mathrm{Ar}$ values range between 8500 and close to the atmospheric value (298.6; Lee et al., 2006), i.e. samples with low ${ }^{40} \mathrm{Ar} /{ }^{36} \mathrm{Ar}$ values do not have $\delta^{15} \mathrm{~N}$ values closer to air ( $0 \%$ o). Finally, off-axis samples are characterised by markedly different ${ }^{4} \mathrm{He} /{ }^{40} \mathrm{Ar}^{*}$ ratios - a parameter sensitive to magma degassing due to the factor of $\sim 10$ difference in solubility between $\mathrm{He}$ and $\mathrm{Ar}$ in basaltic melt (Lux, 1987). Although ${ }^{4} \mathrm{He} /{ }^{40} \mathrm{Ar}^{*}$ ratios vary between 5-31 for samples D18-1 and D26-2, respectively, their $\delta^{15} \mathrm{~N}$ values are virtually identical at 1.14 and $0.89 \%$ o (Fig. 1d). Thus, we conclude that the range in $\delta^{15} \mathrm{~N}$ values reported here reflects intrinsic mantle source features, likely related to subduction of ${ }^{15} \mathrm{~N}$-enriched oceanic sediments and/or oceanic crust

The neon isotope characteristics of CIR lavas are plotted on a traditional three-isotope Ne diagram (Fig. S-2). We note that all samples lie intermediate to air-DMM and air-Réunion mixing trajectories with no clear distinction between on- and off-axis samples. Thus, all CIR basalts comprise three Ne components: air, a primitive/solar (mantle) Ne component and in-situ nucleogenic ${ }^{21} \mathrm{Ne}$, which has in-grown over time. We subtract the air-derived Ne to yield a mantle ${ }^{21} \mathrm{Ne} /{ }^{22} \mathrm{Ne}$ ratio (the so-called extrapolated value $-\left({ }^{21} \mathrm{Ne} /{ }^{22} \mathrm{Ne} E X\right)$; see Supplementary Information for details). This approach allows us to assess mantle neon features of both on- and off-axis samples without compromise of air contamination, and to compare $\mathrm{Ne}$ isotopes to corresponding $\mathrm{N}$-isotope variations.

In Figure 2, we plot the extrapolated $\mathrm{Ne}$-isotope values $\left({ }^{21} \mathrm{Ne} /{ }^{22} \mathrm{Ne}_{\mathrm{EX}}\right)$ of all basalts against measured $\delta^{15} \mathrm{~N}$ together with endmember compositions for (1) pre-solar nitrogen (PSN), (2) depleted MORB mantle (DMM) and (3) sedimentmodified mantle (SMM). Pure DMM has a $\delta^{15} \mathrm{~N}$ value of $\sim-5 \pm 2 \%$, which reflects mixing between $\mathrm{N}$ incorporated at the time of planetary accretion - small amounts of primordial $\mathrm{N}\left(\delta^{15} \mathrm{~N}<-40 \%\right.$ ), possibly as low as proto-solar-nebula (PSN) nitrogen $\left(\delta^{15} \mathrm{~N}=-383 \pm 8 \%\right.$ ), and nitrogen introduced into the mantle by longterm recycling of atmospheric $(=0 \%$ o $)$ and/or sediment-derived $(=\sim+5$ to $+7 \%$ o components (Marty, 2012). SMM nitrogen reflects superimposition and dominance of recently-added sedimentary $\mathrm{N}$ relative to pure DMM, as observed at convergent margins such as Costa Rica (Fischer et al., 2002). For Ne-isotopes, a DMM ${ }^{21} \mathrm{Ne} /{ }^{22} \mathrm{Ne}$ endmember value $(0.0594)$ is derived by extrapolating the MORB trajectory (Sarda et al., 1988) to the ${ }^{20} \mathrm{Ne} / 22 \mathrm{Ne}$ value of $\mathrm{Ne}-\mathrm{B}(=12.5)$ and noting the ${ }^{21} \mathrm{Ne} /{ }^{22} \mathrm{Ne}$ value at that point. Solar $\mathrm{Ne}$ is defined by the solar wind value of 0.03118 (Trieloff and Kunz, 2005). We assume that subduction of oceanic sediments and crust does not introduce neon (or helium) into the mantle (Hilton et al., 1992) so that DMM and SMM have the same ${ }^{21} \mathrm{Ne} /{ }^{22} \mathrm{Ne}_{\mathrm{Ex}}$ value.

The coupled $\delta^{15} \mathrm{~N}-{ }^{21} \mathrm{Ne} /{ }^{22} \mathrm{Ne}_{\mathrm{EX}}$ characteristics of both sets of basaltic glasses (i.e. on- and off-axis) are compatible with mixing between two distinct endmember compositions (Fig. 2). One endmember, with low $\delta^{15} \mathrm{~N}$ and low ${ }^{21} \mathrm{Ne} /{ }^{22} \mathrm{Ne} e_{\mathrm{EX}}$, is common to both sample suites, with solar gas being the most plausible candidate. In contrast, the second endmember differs between on- and off-axis samples. In the case of CIR on-axis basalts, the endmember has a DMM ${ }^{21} \mathrm{Ne} /{ }^{22} \mathrm{Ne}_{\mathrm{EX}}$ value $(0.060)$ and $\delta^{15} \mathrm{~N}=-2.1 \%$ whereas the off-axis samples project to an endmember with a higher $\delta^{15} \mathrm{~N}\left(\sim 1.3 \%\right.$ o) but the same DMM-like ${ }^{21} \mathrm{Ne} /{ }^{22} \mathrm{Ne}_{\text {Ex }}$ value. Notably, both on- and off-axis endmembers lie on the projection between pure DMM and SMM with the proportion of N derived from SMM clearly greater in off-axis samples versus on-axis samples (Fig. 2). 


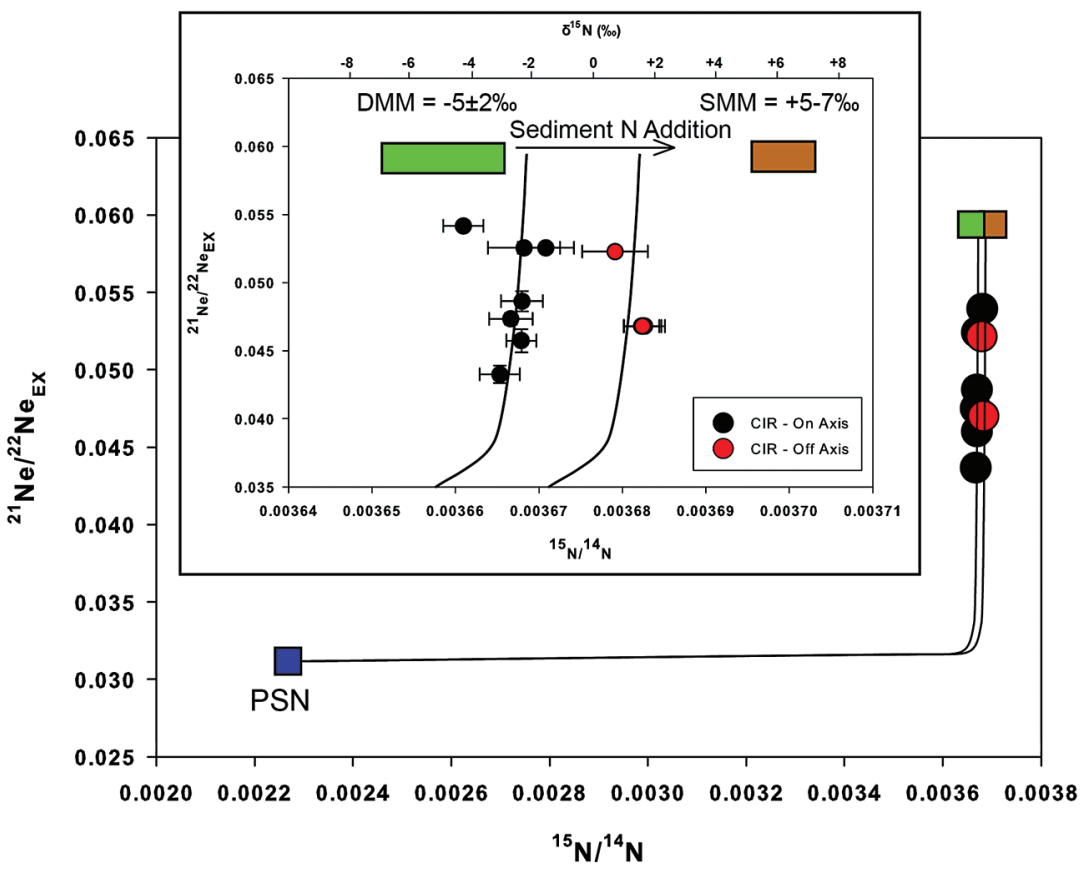

Figure 2 Extrapolated $\mathrm{Ne}\left(\left({ }^{21} \mathrm{Ne} /{ }^{22} \mathrm{Ne}\right)_{\mathrm{Ex}}\right.$, i.e. air-corrected ${ }^{21} \mathrm{Ne} /{ }^{22} \mathrm{Ne}$ values) versus ${ }^{15} \mathrm{~N} /{ }^{14} \mathrm{~N}$ values of $\mathrm{CIR}$ basalts, plotted together with binary mixing curves between a pre-solar nitrogen (PSN) component $\left({ }^{15} \mathrm{~N} /{ }^{14} \mathrm{~N}=0.00227, \delta^{15} \mathrm{~N}=-373 \%\right.$; Marty, 2012) and two mantle endmembe components reflecting addition of ${ }^{15} \mathrm{~N}$-enriched sedimentary MORB mantle $\left(S M M ; \delta^{15} \mathrm{~N}=+5 \%\right.$ ) to DMM mantle $\left(\delta^{15} \mathrm{~N}=-5 \%\right)$. The curvature of the hyperbolic mixing lines is described by the r-value $=\left({ }^{14} \mathrm{~N} / 22 \mathrm{Ne}\right)_{\text {DMM } / \text { SMM }} /\left({ }^{14} \mathrm{~N} / 22 \mathrm{Ne}\right)_{\text {PSN }}$.

The curvature of the binary mixing trajectories in Figure 2 has important implications for the overall recycling efficiency of $\mathrm{N}$ relative to $\mathrm{Ne}$, as it is controlled by the relative ${ }^{14} \mathrm{~N} /{ }^{22} \mathrm{Ne}$ ratios of the two endmembers (r-value). For both on- and off-axis samples, $r \geq 1000$, which indicates either higher relative ${ }^{14} \mathrm{~N}$ or lower ${ }^{22} \mathrm{Ne}$ contents in the mixed DMM-SMM versus the PSN endmember: this indicates that $\mathrm{N}$ is recycled at least $10^{3}$ times more efficiently than Ne into the CIR mantle. Preferential deep recycling of $\mathrm{N}$ relative to $\mathrm{Ne}$ is consistent with recent theoretical and experimental predictions that indicate that $\mathrm{N}$ is stabilised as ammonium under subduction redox conditions ( $\mathrm{fO}_{2}<\mathrm{QFM}$; Mikhail and Sverjensky, 2014) and therefore behaves as a large ion lithophile element whereby it can substitute into K-bearing silicate minerals and gain stability in the downgoing slab (Li et al., 2013). Moreover, mass balance arguments suggest $\mathrm{Ne}$ is efficiently recycled back to the surface during the subduction process (Holland and Ballentine, 2006; Marty, 2012).
The CIR data reaffirms the considerable heterogeneity in mantle $\delta^{15} \mathrm{~N}$ signatures (e.g., Marty and Dauphas, 2003). If we assume that on-axis samples can be used to approximate the N composition of the DMM and that off-axis samples best represent the plume mantle (PLM), then CIR data can be used within the framework of a newly-constructed reference model to place constraints on $\mathrm{N}$ regassing fluxes into the mantle (i.e. both absolute flux values as well as the relative proportions regassing the DMM and PLM reservoirs). Our model is based on a layered mantle reservoir concept, similar to that described for noble gases by O'Nions and Tolstikhin (1996) and Gonnermann and Mukhopadhyay (2009). It makes the following assumptions: (1) the $\mathrm{N}$ regassing flux commences at the onset of subduction and is constant through time; (2) a constant proportion of the total $\mathrm{N}$ regassing flux $(\mathrm{F})$ is subducted into each respective mantle reservoir (defined here as $\mathrm{F}_{\mathrm{DMM}}$ and $\mathrm{F}_{\mathrm{PLM}}$ ) and instantaneously mixes in each reservoir; (3) there is a constant mantle degassing flux of $5 \times 10^{9} \mathrm{~mol} / \mathrm{yr}$ (Cartigny and Marty, 2013), derived from the DMM:PLM reservoirs in the proportion 85:15, respectively (Ito et al., 2003); (4) the present-day mantle $\mathrm{N}$-content ([N]) is $~ 0.27 \pm 0.16 \mathrm{ppm}$ (Marty, 2012; Cartigny and Marty, 2013); and (5) the initial mantle $\delta^{15} \mathrm{~N}$ is - $40 \%$ o (PSN-like; Cartigny and Marty, 2013) which is unmodified by any degassing prior to the onset of subduction. The DMM and PLM reservoirs are considered to have evolved to their current $\delta^{15} \mathrm{~N}$ and [N] compositions, given by the CIR data, as a consequence of additions of different amounts of subducted sedimentary $\mathrm{N}\left(\delta^{15} \mathrm{~N}=+5 \%\right.$ )

A DMM mass of $\sim 9 \times 10^{26} \mathrm{~g}$ (e.g., Anderson, 1989) corresponds to a total inventory of $17.3 \times 10^{18} \mathrm{~mol} \mathrm{~N}$ in the modern-day DMM. Assuming that the mantle degassing flux $\left(5 \times 10^{9} \mathrm{~mol} / \mathrm{yr}\right.$; Cartigny and Marty, 2013) includes all non-arc related $\mathrm{N}$ (i.e. $\mathrm{N}$ degassed from the mantle) and is $85 \%$ DMM-derived $\left(4.3 \times 10^{9} \mathrm{~mol} / \mathrm{yr}\right)$ and $15 \%$ plume mantle-derived $\left(7.5 \times 10^{8} \mathrm{~mol} / \mathrm{yr}\right)$, then a total of $10.6 \times 10^{18} \mathrm{~mol} \mathrm{~N}$ has been degassed from the DMM source over an estimated 2.5 Ga since subduction commenced (e.g., Kusky et al., 2001). For a total N-content of $27.9 \times 10^{18} \mathrm{~mol} \mathrm{~N}$ before degassing, the present-day N-isotopic composition of $-2.1 \%$ must represent admixture between $23.5 \times 10^{18}$ moles of subductionderived $\mathrm{N}\left(\delta^{15} \mathrm{~N}=+5 \%\right.$ ), or $\sim 84 \%$ of the total $\mathrm{N}$, and $4.4 \times 10^{18}$ moles (or $16 \%$ ) of PSN $\left(\delta^{15} \mathrm{~N}=-40 \%\right.$ ). Thus, the time integrated DMM regassing rate $\left(\mathrm{F}_{\mathrm{DMM}}\right)$ is $9.4 \times 10^{9} \mathrm{moles} / \mathrm{yr}$.

Using the same approach for the PLM - assumed to be represented by offaxis high ${ }^{3} \mathrm{He} /{ }^{4} \mathrm{He}$ plume melts with an average $\delta^{15} \mathrm{~N}=1.3 \%$, then a mass of $\sim 3.3 \times 10^{27} \mathrm{~g}$ would contain $64 \times 10^{18} \mathrm{~mol} \mathrm{~N}$ in the modern day plume-influenced mantle. Again assuming a constant mantle degassing flux of $5 \times 10^{9} \mathrm{~mol} / \mathrm{yr}$ (Cartigny and Marty, 2013), of which $15 \%$ (i.e. $7.5 \times 10^{8} \mathrm{~mol} / \mathrm{yr}$ ) is derived from this reservoir (Ito et al., 2003), then a total of $1.9 \times 10^{18} \mathrm{~mol} \mathrm{~N}$ has been degassed from the plume-influenced mantle over $2.5 \mathrm{Ga}$. The total $\mathrm{N}$-content of $65.9 \times 10^{18}$ mol requires $61 \times 10^{18}$ moles $\mathrm{N}\left(\sim 92 \%\right.$ of the total) of subduction-derived $\mathrm{N}\left(\delta^{15} \mathrm{~N}\right.$ $=+5 \%$ ) mixing with $8 \%$ (i.e. $5.4 \times 10^{18}$ moles) of PSN $\left(\delta^{15} \mathrm{~N}=-40 \%\right.$ ) to give the present-day $\mathrm{N}$-isotopic composition of $1.3 \%$. Thus, the model predicts a regassing $\mathrm{N}$-flux $\left(\mathrm{F}_{\mathrm{PLM}}\right.$ ) of $\sim 2.4 \times 10^{10} \mathrm{~mol} / \mathrm{yr}$ since the Archean $(2.5 \mathrm{Ga})$. Importantly, 


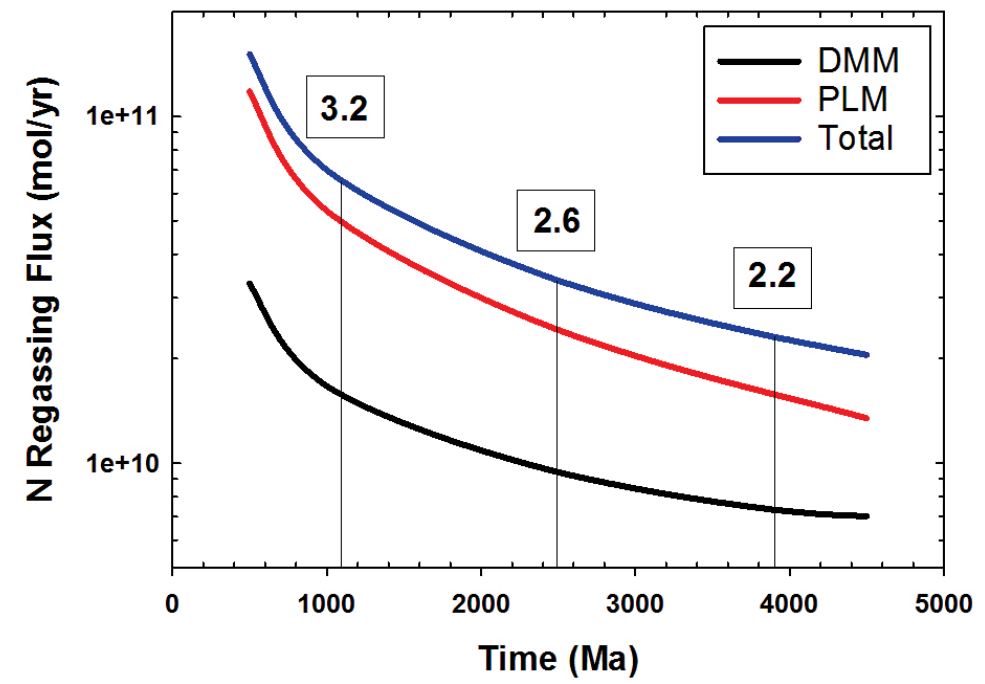

Figure 3 Nitrogen regassing fluxes ( $\mathrm{mol} / \mathrm{yr}$ ) into the mantle as a function of time $(\mathrm{Ma})$ since the onset of subduction. The total flux is equal to the sum of DMM and PLM fluxes. The proportion of $\mathrm{N}$ regassed into the plume-influenced mantle relative to the DMM ( $\left.\mathrm{F}_{\mathrm{PLM}} / \mathrm{F}_{\mathrm{DMM}}\right)$ is shown in boxes at three given time intervals (1.1 Ga, 2.5 Ga, 3.9 Ga).

in order to satisfy the $\mathrm{N}$ systematics for both reservoirs, approximately 2.6 times more $\mathrm{N}$ (i.e. $\mathrm{F}_{\mathrm{PLM}} / \mathrm{F}_{\mathrm{DMM}}$ ) must be subducted into the plume-influenced mantle. If subduction is assumed to have initiated earlier in the geological record (e.g., $3.9 \mathrm{Ga}$; Condie and Pease, 2008), then the $\mathrm{F}_{\mathrm{PLM}} / \mathrm{F}_{\mathrm{DMM}}$ ratio decreases to $\sim 2.2$. Conversely, if an estimated modern day $\mathrm{N}$ input flux of $7 \times 10^{10} \mathrm{~mol} / \mathrm{yr}$ (Cartigny and Marty, 2013) is adopted, it would take the Earth only $1.1 \mathrm{Ga}$ to evolve to its current $\mathrm{N}$ composition, with $\mathrm{F}_{\mathrm{PLM}} / \mathrm{F}_{\mathrm{DMM}}=3.2$ (Fig. 3; Table S-1).

Selection of different $\delta^{15} \mathrm{~N}$ endmembers for mantle reservoirs or lower initial solar values as input parameters has only a minor effect on model results (Table S-1). If more extreme $\mathrm{N}$-isotope estimates of $-4 \%$ ond $+3 \%$ are taken to approximate DMM and PLM sources, respectively (Dauphas and Marty, 1999), then an identical PLM regassing flux of $2.4 \times 10^{10} \mathrm{~mol} / \mathrm{yr}$ is calculated for $2.5 \mathrm{Ga}$ with only a marginally higher $\mathrm{F}_{\mathrm{PLM}} / \mathrm{F}_{\mathrm{DMM}}=2.8$. Alternatively, a significantly higher estimate for the mantle N-content of $\sim 36 \mathrm{ppm}$ (Cartigny and Marty, 2013) results in a $2.5 \mathrm{Ga}$ regassing flux of $3.9 \times 10^{12} \mathrm{~mol} / \mathrm{yr}$ with $\mathrm{a} \mathrm{F}_{\mathrm{PLM}} / \mathrm{F}_{\mathrm{DMM}}=4$ Significantly, all model scenarios point to long-term cycling of subducted $\mathrm{N}$ into Earth's mantle with preferential storage in the deep (plume) mantle (i.e. $\mathrm{F}_{\mathrm{PLM}} / \mathrm{F}_{\mathrm{DMM}}>2$ ). Thus nitrogen not only breaches the subduction barrier beneath arcs but is also transported into the (deep mantle) source region that supplies high ${ }^{3} \mathrm{He} /{ }^{4} \mathrm{He}$ mantle plumes.
Our new reference model has a number of far-reaching implications. First, given the high N recycling efficiencies into DMM (84 \%) and PLM (92 \%) reservoirs, respectively (this work), any losses of slab-derived $\mathrm{N}$ to the atmosphere at volcanic arcs (e.g., by oxidation back to molecular form in the mantle wedge) must be relatively minor. Thus, our model can explain the present-day gross imbalance between the regassing $\mathrm{N}$ flux subducted via trenches and the degassing $\mathrm{N}$ flux returned to the surface via arc-related volcanism (Hilton et al., 2002; Busigny et al., 2011). Second, prior to initiation of subduction-related recycling of $\mathrm{N}$, the total $\mathrm{N}$ content of the atmosphere must have been considerably higher. Our model indicates that the early atmospheric $\mathrm{N}$ content was $\sim 2.1 \times 10^{20}$ moles, or $\sim 50 \%$ higher than at the present-day. Such a high atmospheric N-content would lead to N-enhanced greenhouse warming, and can explain the lack of global glaciations in the early Earth due to the faint young Sun (Goldblatt et al., 2009). Third, subduction of sedimentary $\mathrm{N}$ into the deep mantle would lead to a close relationship between high $\delta^{15} \mathrm{~N}$ values and high ${ }^{3} \mathrm{He} /{ }^{4} \mathrm{He}$ ratios, the canonical geochemical tracer of deep mantle plumes. Recent work on hyaloclastic basaltic glasses in Iceland (Halldórsson et al., 2016) reveals a strong coupling between ${ }^{3} \mathrm{He} /{ }^{4} \mathrm{He}$ and $\delta^{15} \mathrm{~N}$ signatures, consistent with recycling of crustal material to the mantle plume source. Finally, we highlight remarkably similar recycling efficiencies between N (84-92 \%; this work) and heavy noble gases (73-87 \%; Holland and Ballentine, 2006; Parai and Mukhopadhyay, 2012) despite fundamentally different subduction mechanisms: $\mathrm{N}$ is fixed as $\mathrm{NH}_{4}{ }^{+}$and bound in recycled sediments and/or oceanic crust, whereas Kr and Xe undergo no such chemical transformation and instead are simply dissolved in pore fluids and/or in unoccupied amphibole A-sites within subducted oceanic crust (e.g., Holland and Ballentine 2006; Jackson et al., 2015).

\section{Acknowledgements}

This work was supported by NSF grants EAR-0651097 and OCE-0726573. The KNOX11RR cruise was funded by UC Ship Funds. We thank Sami Mikhail, Ben Johnson and anonymous reviewers for their constructive and insightful comments, and Graham Pearson for editorial handling.

Editor: Graham Pearson

\section{Additional Information}

Supplementary Information accompanies this letter at www.geochemicalperspectivesletters.org/article1615

Reprints and permission information is available online at http://www. geochemicalperspectivesletters.org/copyright-and-permissions 
Cite this letter as: Barry, P.H., Hilton, D.R. (2016) Release of subducted sedimentary nitrogen throughout Earth's mantle. Geochem. Persp. Let. 2, 148-159.

\section{References}

ANDERSON, D.L. (1989) Theory of the Earth. Blackwell Scientific Publications, Boston, http://resolver caltech.edu/CaltechBOOK:1989.001.

Barry, P.H., Hilton, D.R., Halldórsson, S.A., Hahm, D., Marti, K. (2012) High precision nitrogen isotope measurements in oceanic basalts using a static triple collection noble gas mas spectrometer. Geochemistry Geophysics Geosystems 13, Q01019.

Bebout, G.E., Lazzeri, K.E., Geiger, C.A. (2016) Pathways for nitrogen cycling in Earth's crust and upper mantle: A review and new results for microporous beryl and cordierite. American Mineralogist 101, 7-24.

Busigny, V., Cartigny, P., Philippot, P. (2011) Nitrogen isotopes in ophiolitic metagabbros: A re-evaluation of modern nitrogen fluxes in subduction zones and implication for the early Earth atmosphere. Geochimica et Cosmochimica Acta 75, 7502-7521.

CARTIGNY, P., MARTY, B. (2013) Nitrogen isotopes and mantle geodynamics: The emergence of life and the atmosphere-crust-mantle connection. Elements 9, 359-366,

CARTIGNY, P., HARRIS, J.W., JAVOY, M. (2001) Diamond genesis, mantle fractionations and mantle nitrogen content: a study of $\delta 13 \mathrm{C}-\mathrm{N}$ concentrations in diamonds. Earth and Planetary Science Letters 185, 85-98.

Condie, K.C., Pease, V. (2008) When did plate tectonics begin on planet Earth? Geological Society of America Special Paper 440, Boulder Colorado, USA.

Dauphas, N., MARTY, B. (1999) Heavy nitrogen in carbonatites of the Kola Peninsula: A possible signature of the deep mantle. Science 286, 2488-2490.

Fischer, T.P., Hilton, D.R., Zimmer, M.M., SHaW, A.M., SHARP, Z.D., WALKer, J.A. (2002) Subduction and recycling of nitrogen along the Central American margin. Science 297, 1154-1157.

FÜri, E., Hilton, D.R., Murton, B.J., Hemond, C., Dyment, J., DaY, J.M.D. (2011) Helium isotope variations between Réunion Island and the Central Indian Ridge $\left(17^{\circ}-21^{\circ} \mathrm{S}\right)$ : new evidence for ridge-hotspot interaction. Journal of Geophysical Research - Solid Earth 116, B02207.

GRAHAM, D.W. (2002) Noble gas isotope geochemistry of mid-ocean ridge and ocean island basalts: Characterization of mantle source reservoirs. RIMS 47, 247-317.

Goldblatt, C., Claire, M.W., Lenton, T.M., Matthews, A.J., Watson, A.J., Zahnle, K.J. (2009) Nitrogen-enhanced greenhouse warming on early Earth. Nature Geoscience 2, 891-896

Gonnermann, H.M., MuKhopadhyay, S. (2009) Preserving noble gases in a convecting mantle. Nature 459, 560-563.

Halldórsson, S.A., Hilton, D.R., BARRY, P.H., FÜrI, E., Gronvold, K. (2016) Recycling of crustal material by the Iceland mantle plume: New evidence from nitrogen elemental an isotope systematics of subglacial basalts. Geochimica et Cosmochimica Acta 176, 206-226.

Hilton, D.R., Hoogewerff, J.A., Van Bergen, M.J., Hammerschmidt, K. (1992) Mapping magma sources in the east Sunda-Banda arcs, Indonesia: constraints from helium isotopes. Geochimica et Cosmochimica Acta 56, 851-859.

Hilton, D.R., FisCher, T.P., MARTY, B. (2002) Noble gases and volatile recycling at subduction zones. Reviews in Mineralogy and Geochemistry 47, 319-370.

HOLLAND, G., BALLENTINE, C.J. (2006) Seawater subduction controls the heavy noble gas composition of the mantle. Nature 441, 186-191.
ITO, G., LIN, J., GRAHAM, D. (2003) Observational and theoretical studies of the dynamics of mantle plume-mid-ocean ridge interaction. Reviews of Geophysics 41, 4.

JaCKSON, C.R., Parman, S.W., KelLeY, S.P., CoOPER, R.F. (2015) Light noble gas dissolution into ring structure-bearing materials and lattice influences on noble gas recycling. Geochimica et Cosmochimica Acta 159, 1-15.

Johnson, B., GoldBlatT, C. (2015) The nitrogen budget of Earth. Earth-Science Reviews 148, 150-173.

KUSKY, T.M., LI, J.H., TUCKER, R.D. (2001) The Archean Dongwanzi ophiolite complex, North China Craton: 2.505-billion-year-old oceanic crust and mantle. Science 292, 1142-1145.

Lee, J.y., Marti, K., Severinghaus, J.P., Kawamura, K., Yoo, H.S., Lee, J.B., Kim, J.S. (2006) A redetermination of the isotopic abundances of atmospheric Ar. Geochimica et Cosmochimica Acta 70, 4507-4512.

LI, L., Bebout, G.E., IDLEMAN, B.D. (2007) Nitrogen concentration and $\delta 15 \mathrm{~N}$ of altered oceanic crust obtained on ODP Legs 129 and 185: insights into alteration-related nitrogen enrichment and the nitrogen subduction budget. Geochimica et Cosmochimica Acta 71, 2344-2360.

LI, Y., Wiedenbeck, M., ShcheKA, S., Keppler, H. (2013) Nitrogen solubility in upper mantle minerals. Earth and Planetary Science Letters 377, 311-323.

LUX, G. (1987) The behavior of noble gases in silicate liquids: Solution, diffusion, bubbles and surface effects, with applications to natural samples. Geochimica et Cosmochimica Acta 51, 1549-1560.

MARTY, B. (2012) The origins and concentrations of water, carbon, nitrogen and noble gases on Earth. Earth and Planetary Science Letters 313-314, 56-66.

MARTY, B., DAUPHAS, N. (2003) The nitrogen record of crust-mantle interaction and mantle convection from Archean to present. Earth and Planetary Science Letters 206, 397-410,

MiKHAIL, S., SVERJENSKY, D.A. (2014) Nitrogen speciation in upper mantle fluids and the origin of Earth's nitrogen-rich atmosphere. Nature Geoscience 7, 816-819.

Mitchell, E.C., Fischer, T.P., Hilton, D.R., Hauri, E.H., Shaw, A.M., De Moor, J.M. SHARP, Z.D. KAZAHAYA, K. (2010) Nitrogen sources and recycling at subduction zones: Insights from the Izu-Bonin-Mariana arc. Geochemistry, Geophysics, Geosystems 11, 2.

MorGAN, W.J. (1978) Rodriguez, Darwin, Amsterdam, a second type of hot spot island. Journal of Geophysical Research 83, 5355-5360.

O'NiONS, R.K., TolSTIKHIN, I.N. (1996) Limits on the mass flux between lower and upper mantle and stability of layering. Earth and Planetary Science Letters 139, 213-222.

Parai, R., Mukhopadhyay, S. (2012) How large is the subducted water flux? New constraints on mantle regassing rates. Earth and Planetary Science Letters 317, 396-406.

SANO, Y., TAKAHATA, N., Nishio, Y., MARTY, B. (1998) Nitrogen recycling in subduction zones Geophysical Research Letters 25, 2289-2292.

Sarda, P., Staudacher, T., AllĖgre, C.J. (1988) Neon isotopes in submarine basalts. Earth and Planetary Science Letters 91, 73-88.

TRIeloff, M., KunZ, J. (2005) Isotope systematics of noble gases in the Earth's mantle: possible sources of primordial isotopes and implications for mantle structure. Physics of the Earth and Planetary Interiors 148, 13-38. 